\title{
Factors Persuading Female Participation towards Entrepreneurial Activities and Its Impact on Employment Creation
}

\author{
Md. Moynul Hasan
}

Assistant Professor, Department of Marketing, Comilla University, Comilla, Bangladesh

\author{
Afzal Hossain \\ MBA Student, Department of Marketing, Comilla University, Comilla, Bangladesh
}

\section{Md Yusuf Hossein Khan}

PhD Researcher in Tourism, University of Algarve, Portugal; Assistant Professor, College of Tourism and Hospitality Management, International University of Business Agriculture and Technology, Bangladesh

\begin{abstract}
Compared to the size of the country where a significant increasement with population is visible and moderately small size of the economy employment creation is a challenging task for Bangladesh. Economic activities are persuaded potential working female to participate in entrepreneurial activities. As a matter of fact, Female entrepreneurship is a very recent phenomenon in Bangladesh. Although female is taking to entrepreneurship in many challenging fields, their activities in Bangladesh are not that wide. In spite of fewer opportunities, many females have succeeded in business, but they are still very small in number.

The main purpose of this investigation is to identify the key factors persuading female participation towards entrepreneurial activities and its impact on employment creation in Chittagong division, Bangladesh. This research adopts quantitative analysis of likely key factors that may persuade female participation towards entrepreneurial activities and its impact on employment creation. The data was collected from 300 respondents by survey method through structured questionnaire with five-point Likert scales and multiple items. Convenience sampling method is used. Data were analyzed using frequency, mean, standard deviation and regression analysis. From the results of regression analysis, this study has found that adequate capital, hard work and persistence, interest and hobby, education, practical knowledge, professional skills and competence, father's occupation, bank and financial institutions support, and geographical location as the vital factors, which significantly persuade female participation towards entrepreneurial activities. This study has also found that female entrepreneur as the important factor, which significantly persuades employment creation. The researchers strongly expect that this paper will create awareness among the entrepreneurs, government and private sectors, academicians, politicians and the stakeholders.
\end{abstract}

Keywords: female participation, entrepreneurial activities, employment creation, economic development, Bangladesh.

JEL Classification: L26, L31.

(C) The Authors, 2018. This article is published with open access at Sumy State University.

\section{Introduction}

Entrepreneurship is strongly recognized as a fundamental component of economic upliftment and a key factor in the effort to lift countries out of poverty (Wolfenson, 2001). Entrepreneurship is the dynamic method of creating, structuring and planning something new with value by dedicating the indispensable in time and effort, assuming the accompanying psychical, productivity, modernization and employment, social risks, financial and receiving the resulting rewards of pecuniary and personal satisfaction and freedom (Hisrich, 2005). Female entrepreneurs are the most important actors in that division and contributors to economic upliftment and are becoming increasingly visible in the local economies of the developing counties (Siwadi \& Mhangami, 2011). Entrepreneurship all over the globe is beginning today as a path for profitable employment, a means of supporting female to assert themselves in the globe of job, and an avenue of improving both their social status and economic (Hassan \& Mugambi, 2013). Bangladesh has undertaken well-regulated reforms across all sectors in the last decade with an emphasis on the initiatives to increase female participation in entrepreneurial activities through confirmatory actions, laws and international conferences to meet quotas to ensure female participation (Groundwork, 2002). 
Therefore, Bangladesh needs to be created female employment. With an increasing population and moderately small size of the economy employment creation is a challenging task for Bangladesh. Economic activities are persuaded potential working female to participate in entrepreneurial activities. As a matter of fact, Female entrepreneurship is a very recent phenomenon in Bangladesh. Although female is taking to entrepreneurship in many challenging fields, their activities in Bangladesh are not that wide. In spite of fewer opportunities, many females have succeeded in business, but they are still very small in number. Larger participation of female in entrepreneurial activities is uplifting their living circumstances and bargaining positions in the households and wider society. Bangladesh has a huge young female and productive workforce that will participate in Entrepreneurial activities and can help to create employment. Therefore, this study is found that adequate capital, hard work \& persistence, interest \& hobby, education, practical knowledge, professional skills \& competence, father's occupation, bank \& financial institutions support, and geographical location as the vital factors, which significantly persuade female participation towards entrepreneurial activities. The paper is also found that female entrepreneur as the important factor, which significantly persuades employment creation.

\section{Literature Review}

The paper exposed that financial \& psychological factors inspiring female to participate entrepreneurial activities and in addition demonstrated that encouragement \& financial support of industry dealing associates, experiences \& sound uplifted specialized network are persuaded female towards entrepreneurial activities. Female are participated in entrepreneurial and manufacturing activities. Female entrepreneurial activities are not simply a means for financially viable but in addition have positive social outcomes for the female themselves and their communal atmosphere United Nations Industrial Development Organization (UNIDO, 2001). The study has revealed that economical, psychological, knowledge and skills, family, and legal \& administrative as the important factors, which notably persuaded female engagement as entrepreneur in Small and Medium Enterprises sector (Afzal, H. et al., 2018). Accessing finance is key factors for female. Female entrepreneurs face the right of entry to credit limitations for incoming an industry. Female have less facility than men to get access to credit for several causes, including lack of collateral, lack of enthusiasm to take into account household assets as security and negative perceptions of female entrepreneur by loan givers (Mahbub, 2000). Technological change is persuaded female participation success in entrepreneurial decision. Technology and interrelated facilities are significantly persuaded female participation success in developing countries (Zewde \& Associates, 2002). Hard work and persistence are appreciably persuaded in female participation in entrepreneurial activities (Afroze, T. et al., 2014). Education and female participation are interrelated (Mark, et al., 2006). Knowledge, skills and previous experience is persuaded in female participation as entrepreneur. Female entrepreneurs have not sufficient education level (Naser, K. et al., 2009). The outcomes of the paper depicted that persuade of family background on female inspiration and female entrepreneurs progress (Bequo \& Gehrels, 2014). The family support, husband's support in meticulous, persuades female's entrepreneurs. Early socialization, children experiences, role models and disclosure in addition have persuaded female to launch their own businesses (Marcellina et al., 2002). Stefanovic, I. et al. (2010) illustrated that security factor are persuaded female entrepreneurs. Gartner (1990) supported that the valence of outcomes associated with participating female towards entrepreneurial activities is related to individuals' motivational levels. Socio-cultural is remarkably persuaded female participation towards entrepreneurial activities (Nilufer, 2001). Administration, sales and personal services are persuaded female participation towards entrepreneurial activities (Dechant \& Al-Lamky, 2005). Religious factor doesn't persuade female entrepreneurship development in Bangladesh (Hossain, A. et al., 2017). Female entrepreneurs face distinctive challenges because of the geographical location and social set up of their enterprise (Farah, 2014). Female entrepreneurs are pivotal to the economy of nation with respect to economic development and employment creation (Coleman \& Kofi, 2008). Galbraith (2008) revealed that the economy of developing nations may be civilizing through entrepreneurship development. Athanne (2011), the paper focused that female entrepreneurs are creating employment and economic development, but female self-enterprises could contribute more. Al-Habees \& Rumman (2012) think that economic development and employment creation move in the favorable indication. All things being equal, the higher economic development is, the lower unemployment rate is. Employment decrease leads to increase in output and economic development, all things being equal. 


\section{Objective of the Research}

The Broad objective of this paper is to identify the key factors persuading female participation towards entrepreneurial activities and its impact on employment creation in Chittagong division, Bangladesh. There are some Specific objectives of this research, which are given below:

a) To determine the level of intend to contribute as entrepreneurs based on socioeconomic characteristics.

b) Explore the key factors persuading for female participating towards entrepreneurial activities.

\section{Conceptual Framework and Research Hypotheses}

\subsection{Proposed research model}

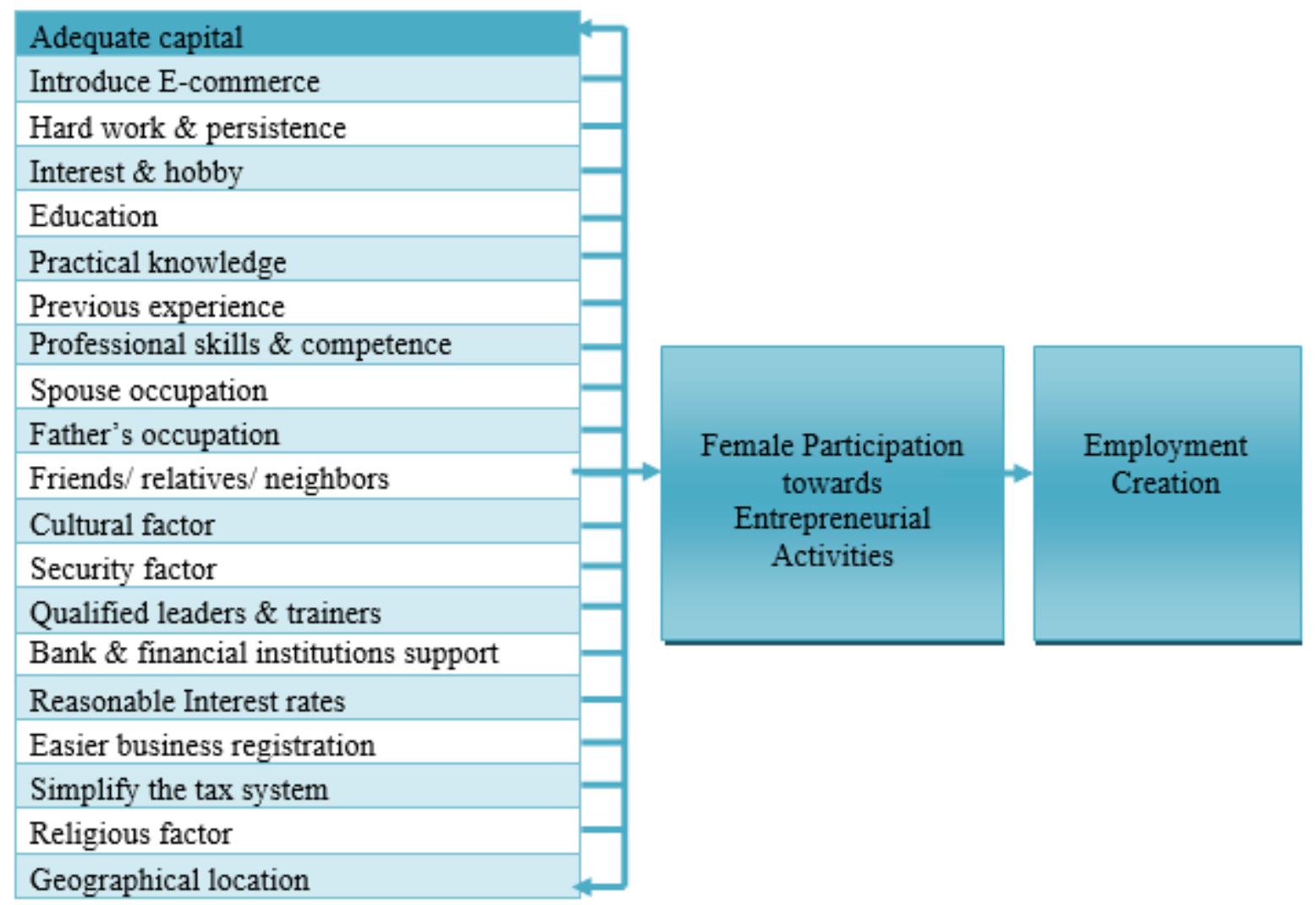

Figure 1.Proposed research model

\subsection{Research Hypotheses}

H1: There is a significant relationship between adequate capital and female participation.

$\mathrm{H} 2$ : There is a significant relationship between introduce e-commerce and female participation.

H3: There is a significant relationship between hard work \& persistence and female participation.

H4: There is a significant relationship between interest \& hobby and female participation.

H5: There is a significant relationship between education and female participation.

H6: There is a significant relationship between practical knowledge and female participation.

H7: There is a significant relationship between previous experience and female participation.

H8: There is a significant relationship between professional skills \& competence and female participation.

H9: There is a significant relationship between spouse occupation and female participation.

H10: There is a significant relationship between father's occupation and female participation.

H11: There is a significant relationship between friends/ relatives/ neighbors and female participation. 
H12: There is a significant relationship between cultural factor and female participation.

H13: There is a significant relationship between security factor and female participation.

H14: There is a significant relationship between qualified leaders $\&$ trainers and female participation.

H15: There is a significant relationship between bank \& financial institutions support and female participation.

H16: There is a significant relationship between reasonable interest rate and female participation.

H17: There is a significant relationship between business registration and female participation.

H18: There is a significant relationship between simplify the tax system and female participation.

H19: There is a significant relationship between religious factor and female participation.

H20: There is a significant relationship between geographical location and female participation.

$\mathrm{H} 21$ : There is a significant relationship between female participation and employment creation.

\section{Research Methodology}

This examination is quantitative. The type of information that is necessary for this study is mainly primary in nature and all data have been collected from primary sources by the personal interview method. On the other hand, from the secondary sources literature review has been developed. A structural question has prepared consists of 27 questions for data collections. The English version of the questionnaire was then translated from English to Bangla. Five questions are related to demographic variables such as age, education qualification, monthly income, marital status, and types of business. Twenty-two questions are about Key factors persuading female participation towards entrepreneurial activities. Therefore, the section 2 is composed of female entrepreneurs measures by using five point Likert scales (from 1= 'Strongly disagree' to $5=$ 'Strongly agree'), those are statements adequate capital, introduce e-commerce, hard work \& persistence, interest \& hobby, education, practical knowledge, previous experience, professional skills \& competence, spouse occupation, father's occupation, friends/ relatives/ neighbors, cultural factor, security factor, qualified leaders \& trainers, bank \& financial institutions support, reasonable interest rate, easier business registration, simplify the tax system, religious factor, and geographical location. Next, Female entrepreneur and employment creation consists of two statements (female participation towards entrepreneurial activities, employment creation). Convenience sampling technique has been used because it is readily available, convenient and generates relatively low cost. Primary data is collected through personal interview from 300 respondents. All constructs have no problems in reliabilities if the Cronbach's Alpha values exceeded the criterion of 0.700 . Cronbach's Alpha is 0.751 for 22 items of variable which suggest that the survey instrument is reliable to quantify all constructs consistently and free from random error. Data collected from questionnaires are analyzed by using various statistical tools like mean, standard deviation and regression analysis by using SPSS 16.0.

\section{Results and Discussions}

Table 1. Descriptive Statistics Analysis

\begin{tabular}{|l|c|c|c|c|c|}
\hline \multicolumn{1}{|c|}{ Factors } & $\mathrm{N}$ & Minimum & Maximum & Mean & S.D. \\
\hline Adequate capital & 300 & 3.00 & 5.00 & $\mathbf{4 . 1 1 0 0}$ & .39421 \\
\hline Introduce E-commerce & 300 & 2.00 & 5.00 & 3.4200 & .53333 \\
\hline Hard work \& persistence & 300 & 1.00 & 5.00 & 2.5800 & 1.04322 \\
\hline Interest \& hobby & 300 & 2.00 & 5.00 & 3.7800 & .71132 \\
\hline Education & 300 & 2.00 & 5.00 & $\mathbf{4 . 2 1 0 0}$ & .53130 \\
\hline Practical knowledge & 300 & 4.00 & 5.00 & $\mathbf{4 . 7 9 0 0}$ & .51841 \\
\hline Previous experience & 300 & 2.00 & 5.00 & $\mathbf{4 . 9 7 0 0}$ & .30011 \\
\hline Professional skills \& competence & 300 & 1.00 & 5.00 & 3.1300 & 1.06339 \\
\hline Spouse occupation & 300 & 1.00 & 5.00 & 3.9400 & 1.36212 \\
\hline Father's occupation & 300 & 1.00 & 5.00 & 2.0600 & 1.23461 \\
\hline Friends/ relatives/ neighbors & 300 & 2.00 & 5.00 & 3.5200 & .75352 \\
\hline Cultural factor & 300 & 1.00 & 5.00 & 3.6300 & .81330 \\
\hline Security factor & 300 & 2.00 & 5.00 & $\mathbf{4 . 3 2 0 0}$ & .56627 \\
\hline
\end{tabular}


Table 1 (cont.). Descriptive Statistics Analysis

\begin{tabular}{|l|c|c|c|c|c|}
\hline \multicolumn{1}{|c|}{ Factors } & $\mathrm{N}$ & Minimum & Maximum & Mean & S.D. \\
\hline Qualified leaders \& trainers & 300 & 2.00 & 5.00 & $\mathbf{4 . 1 7 0 0}$ & .59216 \\
\hline $\begin{array}{l}\text { Bank \& financial institutions } \\
\text { support }\end{array}$ & 300 & 2.00 & 5.00 & 2.1900 & 1.31152 \\
\hline Reasonable interest rate & 300 & 1.00 & 5.00 & $\mathbf{4 . 1 9 0 0}$ & .61152 \\
\hline Easier business registration & 300 & 1.00 & 5.00 & 3.3200 & .82376 \\
\hline Simplify the tax system & 300 & 1.00 & 4.00 & 2.2200 & .61142 \\
\hline Religious factor & 300 & 2.00 & 5.00 & 3.8700 & .67198 \\
\hline Geographical location & 300 & 1.00 & 5.00 & 3.2100 & .89774 \\
\hline
\end{tabular}

\subsection{Summary of the key factors that persuade female participation}

Table 1 reveals that explore the key factors that persuade female participation towards entrepreneurial activities in Chittagong division, Bangladesh. Majority of the respondents are agreed with adequate capital (mean score is 4.1100). Therefore, adequate capital is significantly persuaded female participation towards entrepreneurial activities. Most of the respondents are agreed with education (mean score is 4.2100). As a result, education is appreciably persuaded female participation towards entrepreneurial activities. Majority of the respondents are agreed with practical knowledge (mean score is 4.7900). Thus, practical knowledge is considerably persuaded female participation towards entrepreneurial activities. Most of the respondents are agreed with previous experience (mean score is 4.9700). So, previous experience is noticeably persuaded female participation towards entrepreneurial activities. Most of the respondents are agreed with security factor (mean score is 4.3200). Hence, security factor is noticeably persuaded female participation towards entrepreneurial activities. Most of the respondents are agreed with qualified leaders \& trainers (mean score is 4.1700). For this reason, qualified leaders \& trainers are distinctly persuaded female participation towards entrepreneurial activities. Most of the respondents are agreed with reasonable interest rate (mean score is 4.1900). Hence, reasonable interest rate is noticeably persuaded female participation towards entrepreneurial activities. Therefore, from the results of descriptive statistics analysis that adequate capital, education, practical knowledge, previous experience, security factor, qualified leaders $\&$ trainers, and reasonable interest rate are significantly persuaded female participation towards entrepreneurial activities in Chittagong division, Bangladesh.

\subsection{Result of regression analysis}

Table 2. Predict the relationship between key factors and female participation

\begin{tabular}{|c|c|c|c|c|}
\hline \multicolumn{5}{|c|}{ Model Summary } \\
\hline Model & R & R Square & Adjusted R Square & Std. Error of the Estimate \\
\hline 1 & $\mathbf{. 8 6 9}^{\mathbf{a}}$ & $\mathbf{. 7 5 4}$ & $\mathbf{. 7 3 7}$ & .21459 \\
\hline
\end{tabular}

\subsubsection{Predict the relationship between key factors and female participation}

Table 2 presents that the value of correlation coefficient, $\mathrm{R}=0.869$ suggests that there is moderate positive correlation between female participation towards entrepreneurial activities and adequate capital, introduce ecommerce, hard work \& persistence, interest \& hobby, education, practical knowledge, previous experience, professional skills \& competence, spouse occupation, father's occupation, friends/ relatives/ neighbors, cultural factor, security factor, qualified leaders \& trainers, bank \& financial institutions support, reasonable interest rate, easier business registration, simplify the tax system, religious factor, and geographical location. However only $75.4 \%$ (R-square values of 0.754 ) variation in female participation is accounted due to adequate capital, introduce e-commerce, hard work \& persistence, interest \& hobby, education, practical knowledge, previous experience, professional skills \& competence, spouse occupation, father's occupation, friends/ relatives/ neighbors, cultural factor, security factor, qualified leaders \& trainers, bank \& financial institutions support, reasonable interest rate, easier business registration, simplify the tax system, religious factor, and geographical location.

\subsubsection{Confirm the relationship model fitness}

Table 3 reveals that multiple regression analysis is performed to explore the relationship between adequate capital, introduce e-commerce, hard work \& persistence, interest \& hobby, education, practical knowledge, previous experience, professional skills \& competence, spouse occupation, father's occupation, friends/ 
relatives/ neighbors, cultural factor, security factor, qualified leaders \& trainers, bank \& financial institutions support, reasonable interest rate, easier business registration, simplify the tax system, religious factor, and geographical location with female participation towards entrepreneurial activities. Twenty hypotheses are proposed, and results are enumerated in Table 3. The F-statistics produced $(\mathrm{F}=42.853)$ is significant at 1 percent level (Sig. F < 0.01) with 20 and 279 degree of freedom, Thus confirming the fitness for the model. The adjusted R2 is 0.737 (From table 2), connoting that the twenty factors can significantly account for $73.7 \%$ variance in female participation towards entrepreneurial activities.

Table 3. Confirming the relationship model fitness

\begin{tabular}{|c|c|c|c|c|c|c|}
\hline \multicolumn{7}{|c|}{ ANOVA } \\
\hline \multicolumn{2}{|c|}{ Model } & Sum of Squares & df & Mean Square & $\mathrm{F}$ & Sig. \\
\hline \multirow[t]{3}{*}{1} & Regression & 39.465 & 20 & 1.973 & 42.853 & $.000^{\mathrm{a}}$ \\
\hline & Residual & 12.847 & 279 & .046 & & \\
\hline & Total & 52.313 & 299 & & & \\
\hline
\end{tabular}

\subsubsection{Key factors persuading female participation towards entrepreneurial activities}

The results of multiple regression analysis for $\mathrm{H} 1$ as presents in Table 4 that adequate capital as the key factor, which positively and significantly persuades female participation in entrepreneurial activities $(\beta 1=0.114$; $\mathrm{t}$ value $=3.297 ; \mathrm{p}<0.05)$. H1 is accepted. Therefore, adequate capital is persuaded female participation towards entrepreneurial activities. The results for $\mathrm{H} 3$ as shows that hard work \& persistence as the vital factor, which positively and notably persuade female participation in entrepreneurial activities $(\beta 3=0.423$; $\mathrm{t}$-value $=12.520$; $p<0.05)$. H3 is accepted. Hence, hard work \& persistence are persuaded female participation towards entrepreneurial activities. Next, $\mathrm{H} 4$ substantiates that interest \& hobby as the key factor, which positively and significantly persuade female participation in entrepreneurial activities $(\beta 4=.595$; $\mathrm{t}$-value $=17.538, p<0.05)$. $\mathrm{H} 4$ is accepted. For this reason, interest $\&$ hobby are persuaded female participation towards entrepreneurial activities. Next, H5 presents that education as the major factor, which negatively and considerably persuades female participation in entrepreneurial activities $(\beta 5=-.123$; $\mathrm{t}$-value $=-3.413 ; \mathrm{p}<0.05)$. H5 is accepted. Thus, education is persuaded female participation towards entrepreneurial activities. Next, H6 substantiates that practical knowledge as the chief factor, which positively and significantly persuades female participation in entrepreneurial activities $(\beta 6=.094$; t-value $=2.686, p<0.05)$. H6 is accepted. Consequently, practical knowledge is persuaded female participation towards entrepreneurial activities. Next, H8 substantiates that professional skills \& competence as the chief factor, which positively and remarkably persuade female participation in entrepreneurial activities $(\beta 8=.092$; $\mathrm{t}$-value $=2.480, p<0.05)$. H8 is accepted. So, professional skills \& competence are persuaded female participation towards entrepreneurial activities. Next, H10 presents that father's occupation as the main factor, which negatively and significantly persuades female participation in entrepreneurial activities $(\beta 10=-.068$; $\mathrm{t}$-value $=-2.023 ; \mathrm{p}<0.05)$. H10 is accepted. Thus, father's occupation is persuaded female participation towards entrepreneurial activities. Next, H15 presents that bank \& financial institutions as the core factor, which negatively and appreciably persuade female participation in entrepreneurial activities $(\beta 15=-.074$; $\mathrm{t}$-value $=-2.102 ; p<0.05)$. H15 is accepted. Therefore, bank \& financial institutions are persuaded female participation towards entrepreneurial activities. Next, H20 substantiates geographical location as the important factor, which positively and significantly persuades female participation in entrepreneurial activities $(\beta 20=.093$; $\mathrm{t}$-value $=2.634, p<0.05)$. $\mathrm{H} 20$ is accepted. As a result, geographical location is persuaded female participation towards entrepreneurial activities.

Table 4. Key factors persuading female participation towards entrepreneurial activities

\begin{tabular}{|c|c|c|c|c|c|c|}
\hline \multicolumn{7}{|c|}{ Coefficients $^{\mathrm{a}}$} \\
\hline & \multirow[t]{2}{*}{ Model } & \multicolumn{2}{|c|}{$\begin{array}{c}\text { Unstandardized } \\
\text { Coefficients }\end{array}$} & \multirow{2}{*}{$\begin{array}{c}\text { Standardized } \\
\text { Coefficients } \\
\text { Beta } \\
\end{array}$} & \multirow[t]{2}{*}{$\mathrm{t}$} & \multirow[t]{2}{*}{ Sig. } \\
\hline & & $\mathrm{B}$ & Std. Error & & & \\
\hline \multirow{6}{*}{1} & (Constant) & .483 & .328 & & 1.473 & .142 \\
\hline & Adequate capital (H1) & .105 & .032 & .114 & 3.297 & .001 \\
\hline & Introduce E-commerce (H2) & .039 & .027 & .060 & 1.469 & .143 \\
\hline & Hard work \& persistence (H3) & .282 & .023 & .423 & 12.520 & .000 \\
\hline & Interest \& hobby (H4) & .368 & .021 & .595 & 17.538 & .000 \\
\hline & Education (H5) & -.056 & .016 & -.123 & -3.413 & .001 \\
\hline
\end{tabular}


Table 4 (cont.). Key factors persuading female participation towards entrepreneurial activities

\begin{tabular}{|c|c|c|c|c|c|}
\hline \multicolumn{6}{|c|}{ Coefficients $^{\mathrm{a}}$} \\
\hline \multirow[t]{2}{*}{ Model } & \multicolumn{2}{|c|}{$\begin{array}{c}\text { Unstandardized } \\
\text { Coefficients }\end{array}$} & \multirow{2}{*}{$\begin{array}{c}\begin{array}{c}\text { Standardized } \\
\text { Coefficients }\end{array} \\
\text { Beta }\end{array}$} & \multirow[t]{2}{*}{$\mathrm{t}$} & \multirow[t]{2}{*}{ Sig. } \\
\hline & $\mathrm{B}$ & Std. Error & & & \\
\hline Practical knowledge (H6) & .086 & .032 & .094 & 2.686 & .008 \\
\hline Previous experience $(\mathrm{H} 7)$ & .011 & .022 & .015 & .477 & .634 \\
\hline Professional skills \& competence (H8) & .036 & .014 & .092 & 2.480 & .014 \\
\hline Spouse occupation (H9) & .013 & .011 & .040 & 1.157 & .248 \\
\hline Father's occupation (H10) & -.025 & .012 & -.068 & -2.023 & .044 \\
\hline Friends/ relatives/ neighbors (H11) & .022 & .017 & .044 & 1.236 & .217 \\
\hline Cultural factor (H12) & .004 & .016 & .008 & .237 & .813 \\
\hline Security factor (H13) & -.004 & .019 & -.007 & -.186 & .852 \\
\hline Qualified leaders \& trainers (H14) & .027 & .021 & .043 & 1.290 & .198 \\
\hline Bank \& financial institutions (H15) & -.053 & .025 & -.074 & -2.102 & .036 \\
\hline Reasonable interest rate (H16) & -.024 & .013 & -.059 & -1.826 & .069 \\
\hline Business registration (H17) & -.025 & .029 & -.029 & -.868 & .386 \\
\hline Simplify the tax system (H18) & -.016 & .015 & -.036 & -1.063 & .289 \\
\hline Religious factor (H19) & -.031 & .040 & -.030 & -.777 & .438 \\
\hline Geographical location (H20) & .101 & .038 & .093 & 2.634 & .009 \\
\hline
\end{tabular}

The findings in Table 4 corroborates that e-commerce insignificantly persuades female participation in entrepreneurial activities $(\beta 2=.060 ; \mathrm{t}$-value $=1.469 ; p>0.05)$. $\mathrm{H} 2$ is not accepted. Therefore, e-commerce has no effects female participation towards entrepreneurial activities. Next, $\mathrm{H} 7$ substantiates that previous experience insignificantly persuades female participation in entrepreneurial activities $(\beta 7=.015 ; \mathrm{t}$-value $=.477 ; p>0.05)$. H7 is also not accepted. As a result, previous experience has no effects female participation towards entrepreneurial activities. Next, $\mathrm{H} 9$ demonstrates that spouse occupation insignificantly persuades female participation in entrepreneurial activities $(\beta 9=.040 ; \mathrm{t}$-value $=1.157 ; p>0.05)$. H9 is also not accepted. Consequently, spouse occupation has no effects female participation towards entrepreneurial activities. Next, H11 presents that friends/ relatives/ neighbors insignificantly persuade female participation entrepreneurial activities ( $\beta 11=.044 ; \mathrm{t}$-value $=1.236 ; p>0.05)$. H11 is not accepted. Thus, friends/ relatives/ neighbors have no effect female participation towards entrepreneurial activities. Next, H12 substantiates that cultural factor insignificantly persuades female participation in entrepreneurial activities $(\beta 12=.008$; t-value $=.237 ; p>0.05)$. H12 is also not accepted. So, cultural factor has no effects female participation towards entrepreneurial activities. Next, H13 corroborates that security factor negatively and insignificantly persuades female participation in entrepreneurial activities $(\beta 13=-.007$; $\mathrm{t}$-value $=-.186 ; p>0.05)$. H13 is not accepted. As a result, security factor has no effects female participation towards entrepreneurial activities. Next, H14 substantiates that qualified leaders $\&$ trainers insignificantly persuade female participation in entrepreneurial activities $(\beta 14=.043$; $\mathrm{t}$-value $=1.290 ; p>0.05)$. H14 is not accepted. So, qualified leaders \& trainers have no effect female participation towards entrepreneurial activities. Next, H16 depicts that reasonable interest rate negatively and insignificantly persuades female participation in entrepreneurial activities $(\beta 16=-.059 ; \mathrm{t}$-value $=-1.826 ; p>0.05)$. H16 is not accepted. So, reasonable interest rate has no effects female participation towards entrepreneurial activities. Next, H17 substantiates that business registration negatively and insignificantly persuades female participation in entrepreneurial activities $(\beta 17=-.029 ; \mathrm{t}$-value $=-.868 ; p>0.05)$. H17 is not accepted. For that reason, business registration has no effects female participation towards entrepreneurial activities. Next, H18 substantiates that simplify the tax system negatively and insignificantly persuades female participation in entrepreneurial activities $(\beta 18=-.036$; $\mathrm{t}$-value $=-1.063 ; p>0.05)$. H18 is not accepted. Hence, simplify the tax system has no effects female participation towards entrepreneurial activities. Next, H19 confirms that religious factor negatively and insignificantly persuades female participation in entrepreneurial activities $(\beta 19=-.029$; $\mathrm{t}$-value $=-.868 ; p>0.05)$. H19 is not accepted. That's why; religious factor has no effects female participation towards entrepreneurial activities. 


\subsubsection{Confirm the relationship between female participation and employment creation}

Table 5 exposes that the value of correlation coefficient, $\mathrm{R}=0.261$ suggests that there is moderate positive correlation between female participation and employment creation. However only $6.8 \%$ (R-square values of 0.068) variation in recommend is accounted due to employment creation.

Table 5. Confirm the relationship between female participation and employment creation

\begin{tabular}{|c|c|c|c|c|}
\hline \multicolumn{5}{|c|}{ Model Summary } \\
\hline Model & $\mathrm{R}$ & R Square & Adjusted R Square & $\begin{array}{c}\text { Std. Error of the Esti- } \\
\text { mate }\end{array}$ \\
\hline 1 & $.261^{\text {a }}$ & $\mathbf{. 0 6 8}$ & $\mathbf{. 0 6 5}$ & $\mathbf{. 4 9 6 2 6}$ \\
\hline
\end{tabular}

\subsubsection{Confirm the relationship model fitness}

Multiple regression analysis is performed to examine the relationship between female participation and employment creation. The outcomes are enumerated in Table 6 . The F-statistics produced $(\mathrm{F}=21.751)$ is significant at 1 percent level (Sig. F < 0.01) with 1 and 298 degree of freedom, thus confirming the fitness for the model. The adjusted R2 is 0.065 (From table 5), connoting that female participation may notably account for $11.3 \%$ variance in employment creation.

Table 6. Confirm the relationship model fitness

\begin{tabular}{|c|c|c|c|c|}
\hline \multicolumn{5}{|c|}{ ANOVA $^{\mathbf{b}}$} \\
\hline Sum of Squares & df & Mean Square & F & Sig. \\
\hline 5.357 & 1 & 5.357 & $\mathbf{2 1 . 7 5 1}$ & $\mathbf{. 0 0 0}^{\mathbf{a}}$ \\
\hline 73.390 & 298 & .246 & & \\
\hline 78.747 & 299 & & & \\
\hline
\end{tabular}

Table 7. Female participation persuades employment creation

\begin{tabular}{|c|c|c|c|c|c|c|}
\hline \multicolumn{7}{|c|}{ Coefficients $^{\mathrm{a}}$} \\
\hline & \multirow[t]{2}{*}{ Model } & \multicolumn{2}{|c|}{ Unstandardized Coefficients } & \multirow{2}{*}{$\begin{array}{c}\text { Standardized } \\
\text { Coefficients }\end{array}$} & \multirow[t]{2}{*}{$\mathrm{t}$} & \multirow[t]{2}{*}{ Sig. } \\
\hline & & $\mathrm{B}$ & Std. Error & & & \\
\hline \multirow[b]{2}{*}{1} & (Constant) & 3.426 & .251 & & 13.674 & .000 \\
\hline & $\begin{array}{l}\text { Female participation towards } \\
\text { entrepreneurial activities }\end{array}$ & .274 & .059 & .261 & 4.664 & .000 \\
\hline
\end{tabular}

\subsubsection{Female participation persuades employment creation}

The results of multiple regression analysis as presents in Table 7 female participation as the vital factor, which significantly persuades employment creation $(\beta 21=0.261$; $\mathrm{t}$-value $=4.664 ; \mathrm{p}<0.05)$. H21 is accepted. Therefore, there is significant relation between female participation and employment creation.

\subsection{The demographic profile of respondents}

Table A (see in Appendix) presents the descriptive exploration on demographic profile of respondents. It appears that respondents are mostly in the age categories 31-40 years old (33.0\%). The second highest of respondents are in the age categories $21-30$ years $(28.0 \%)$. The third highest of respondents are in the age categories $41-50$ years (20.3\%), and Minority of respondents are in the age categories 50 years above (18.7\%). With regards to educational qualification, $56.6 \%$ of respondents are secondary level, $25.0 \%$ of respondents are $\mathrm{BA}, \mathrm{BBA}$ and BCom. 9.3\% of the respondents are below secondary. $6.7 \%$ of respondents are diploma and only $2.4 \%$ respondents are MA, MBA and MSc. These most of the respondents are secondary and minority of the respondent is postgraduate. It presents that respondents are majority in the income level 51,000-50,000 $(50 \%)$, the second highest of respondents are income level 31,000-50,000 (33.3\%), the third highest of respondents are income level below 30,000(11\%) and minority of respondents are income level 70,000 above (5.7\%). $63.3 \%$ of those who have participated in the survey are married. $18.7 \%$ are single, and $11.3 \%$ are Divorced. Minority of respondents are widow (6.7\%). Also with regard to participate female what types of business, majority of female are participated in Textiles (32\%), the second highest of female are participated in Chemicals and pharmaceuticals (20.3\%), the third highest of the female are participated in Handicrafts (13\%), the fourth highest of female are participated both in Food \& Allied, and Others (10\%), the fifth highest 
of female are participated in Paper and Printing (6\%), the sixth highest of female are participated in agro based business (5\%), and minority of female are participated in Engineering (3.7\%).

\section{Conclusion and Implications}

The study has been undertaken with an objective is to identify the key factors that persuade female participation towards entrepreneurial activities and its impact on employment creation in Chittagong division, Bangladesh. Particular key factors are major tools to motivate female participation towards entrepreneurial activities. This paper investigates adequate capital, introduce e-commerce, hard work \& persistence, interest \& hobby, education, practical knowledge, previous experience, professional skills \& competence, spouse occupation, father's occupation, friends/ relatives/ neighbors, cultural factors, security, qualified leaders \& trainers, bank \& financial institutions support, reasonable interest rate, easier business registration, simplify the tax system, religious, and geographical location are likely key factors that persuade female participation towards entrepreneurial activities in Chittagong division, Bangladesh. From the results of regression analysis, this study is found that adequate capital, hard work \& persistence, interest \& hobby, education, practical knowledge, professional skills \& competence, father's occupation, bank \& financial institutions support, and geographical location as the vital factors, which significantly persuade female participation towards entrepreneurial activities. The paper is also found that female entrepreneur as the important factor, which significantly persuades employment creation. This research is also presented those female face problems in participating entrepreneurial activities in Chittagong division, Bangladesh. From regression analysis, introduce e-commerce, previous experience, spouse occupation, friends/ relatives/ neighbors, cultural factors, security, qualified leaders and trainers, reasonable interest rate, easier business registration, simplify the tax system and religious are not persuaded female participation towards entrepreneurial activities in Chittagong division. This paper will be contributed to these female entrepreneur issues. The outcomes of this research can be applied by government and non-government organization, local business community, rural development academy to encourage female participation towards entrepreneurial activities in Chittagong division, Bangladesh.

\section{Limitation and Further Research}

This data may not be the real representative of overall Bangladeshi female entrepreneurs due to sample area and size. The study found some persuades of independent variable. As a result, there may be some other variable which may persuade female participation towards entrepreneurial activities. Those factors are left for future exploration. The paper is confined just female respondents who have already worked in entrepreneurial activities in Chittagong division. That's why; the researcher suggests that the further research will be conducted in a larger area.

\section{References}

1. Afroze, T., Alam, M.K., Akther, E. and Jui, N.S. (2014). Female Entrepreneurs in Bangladesh - Challenges and Determining Factor. Journal of Business and Technology (Dhaka), 9(02), 27-39.

2. Afzal, H., Zillur, R. S. and Abdullah, A. J., (2018). Factors Affecting Women Involvement as Entrepreneur in SMEs Sector, Economic Development and Its Impact on Poverty Reduction in Bangladesh. Business, Management and Economics Research, 4(5), 51-65.

3. Al-Habees, M.A., \& Rumman, A.M. (2012). The Relationship between Unemployment and Economic Growth in Jordan and Some Arab Countries. World Applied Sciences Journal, 18(5), 673-680.

4. Athanne (2011). Entrepreneurship in Kenya, Nairobi.

5. Beqo, I. and Gehrels, S.A. (2014). Female entrepreneurship in developing countries. Research in Hospitality Management, 4(1\&2), 97-104.

6. Coleman, A. \& Kofi, O. (2008). Outreach of profitability of microfinance institutions: The role of government. Journal of Economic Studies, 53(3), 236-248.

7. Decent, K. and Al-Lamky, A. (2005). Toward an understanding of Arab women entrepreneurs in Bahrain and Oman. Journal of Development Entrepreneurship, 10(2), 123-140.

8. Farah, A.I. (2014). Factors Influencing Women Participation in Entrepreneurial Activities in Mandera Township. Mandera Central Division, Kenya.

9. Gartner, W.B. (1990). What are we talking about when we talk about Entrepreneurship? Journal of Business Venturing, 5, 15-28.

10. Galbraith, C. S. (2008). Editorial: Economic development and entrepreneurship research. International Journal of Entrepreneurship and Small Business, 6(4), 517-519. 
11. GroundWork (2002). Bangladesh Education Sector Review, Report No-2, Overview of the status of the Gender Equity, GroundWork, Inc., 1825 Eye Street, N.W., Suite 400, Washington, D.C.

12. Hisrich, R.D. (2005). Entrepreneurship, Tata McGraw Hill, New Delhi.

13. Hassan, I.B. and Mugambi, F. (2013). Determinants of Growth for Women Owned and Operated Micro Enterprises: The case of Garissa, Kenya. International Journal of Business and Commerce, 2(7), 45-55.

14. Hossain, A., Naser, K., Zaman, A. and Nuseibeh, N. (2009). Factors influencing Female business development in the developing countries evidence from Bangladesh. International Journals of Organizational Analysis, 17(3), 202-224.

15. Mahbub, U.H. (2000). Human Development Centre, Human Development in South Asia: The Gender Question (Oxford University Press), Disadvantages and self- enterprises. Female in Management Review, 19(1), 5-17.

16. Marcellina, C., Donath, R.O. and Mariam, N. (2002). Jobs, gender and small enterprise in Tanzania: factors affecting Female entrepreneurs in the MSE sector. ILO Working Paper.

17. Mark, W., Dickson, P. and Wake, F.(2006) .Entrepreneurship and education: what is known and not known about the links between education and entrepreneurial activity. The Small Business economy for Data Year 2005: A report to the President, USA Government printing office, Washington, DC, pp. 84-113.

18. Naser, K., Mohammed, R.W. and Nuseibeh, R. (2009). Factors that affect Female entrepreneurs: evidence from an emerging economy. International Journals of Organizational Analysis, 17(3), 225-247.

19. Nilufer, A. (2001). Jobs, gender and small enterprises in Bangladesh: factors affecting women enterprises in small and cottage industries in Bangladesh. SEED Working paper No. 14, International Labor Office, Geneva.

20. Siwadi, P., Mhangami, M. (2011). An analysis of the performance of Female entrepreneurs in a Multi-currency economy: the case of Midlands's province of Zimbabwe. University of Botswana Journal.

21. Stefanovic, I., Prokic, S. and Rankovic, L. (2010). Motivational and success factors of entrepreneurs: the evidence from a developing country. Original scientific paper, 28(2), 251-269.

22. UNIDO (2001). Female Entrepreneurship Development in Selected African Countries. Working Paper No. 7, Legos.

23. Wolfenson, J.D. (2001). Comparing the performance of male and female-controlled businesses: relating output to inputs. Entrepreneurship Theory and Practice, 26(3), 91-100.

24. Zewde and associates (2002). Jobs, gender and small enterprise in Africa: the study of Female's entrepreneurship development in Ethiopia. Paper presented at national Conference on Female's entrepreneurship Development in Ethiopia, Addis Ababa, Ethiopia, November 18.

\section{Appendix}

Table A. The Demographic profile of respondents

\begin{tabular}{|c|c|c|}
\hline Variable & Frequency & Percentage \\
\hline $\begin{array}{c}\text { Age } \\
\text { 21-30 Years } \\
\text { 31-40 Years } \\
41-50 \text { Years } \\
50 \text { Years + } \\
\text { Education Qualification } \\
\text { Below secondary } \\
\text { Secondary } \\
\text { Diploma } \\
\text { BA, BBA, and BCom } \\
\text { MA, MBA, and MSc } \\
\text { Monthly Income } \\
\text { Below 30,000 } \\
\text { 31,000-50,000 } \\
\text { 51,000-70,000 } \\
\text { 70,0000 above } \\
\text { Marital Status } \\
\text { Single } \\
\text { Married } \\
\text { Divorced } \\
\text { Widow } \\
\text { Type of Business } \\
\text { Food and Allied } \\
\text { Chemicals and pharmaceuticals } \\
\text { Handicrafts } \\
\text { Paper and Printing } \\
\text { Textiles } \\
\text { Engineering } \\
\text { Agro-based } \\
\text { Others }\end{array}$ & $\begin{array}{c}84 \\
99 \\
61 \\
56 \\
\\
28 \\
170 \\
20 \\
75 \\
7 \\
\\
33 \\
100 \\
150 \\
17 \\
\\
56 \\
190 \\
34 \\
20 \\
\\
30 \\
61 \\
39 \\
18 \\
96 \\
11 \\
15 \\
30\end{array}$ & $\begin{array}{c}28.0 \\
33.0 \\
20.3 \\
18.7 \\
\\
9.3 \\
56.6 \\
6.7 \\
25.0 \\
2.4 \\
\\
11.0 \\
33.3 \\
50.0 \\
5.7 \\
\\
18.7 \\
63.3 \\
11.3 \\
6.7 \\
\\
10.0 \\
20.3 \\
13.0 \\
6.0 \\
32.0 \\
3.7 \\
5.0 \\
10.0\end{array}$ \\
\hline
\end{tabular}

